\title{
SPINAL METASTASIS: DIAGNOSIS, TREATMENT AND PROGNOSIS - INTEGRATIVE REVIEW FROM 2012 TO 2017
}

\author{
METÁSTASES DA COLUNA VERTEBRAL: DIAGNÓSTICO, TRATAMENTO E PROGNÓSTICO - \\ REVISÃO INTEGRATIVA DE 2012 A 2017
}
METÁSTASIS DE LA COLUMNA VERTEBRAL: DIAGNÓSTICO, TRATAMIENTO Y PRONÓSTICO - REVISIÓN INTEGRATIVA DE 2012 A 2017

PAulo Rogério CORTEZ $1,2,3,4$

\author{
1. Universidade Federal Fluminense, Hospital Universitário Antônio Pedro - HUAP-UFF, Niterói, RJ, Brazil. \\ 2. Hospital Estadual Azevedo Lima - HEAL, Niterói, RJ, Brazil. \\ 3. Hospital Federal do Andaraí - HFA, Rio de Janeiro, RJ, Brazil. \\ 4. Centro de Saúde da Coluna - CSC, Niterói, RJ, Brazil.
}

\begin{abstract}
Care of the patient with spinal metastasis is challenging. The topic of this article is the treatment and prognosis of spinal metastases, aiming to enumerate and analyze literature that addresses this treatment and prognosis. The methodology used was an integrative review in the Virtual Health Library. Nineteen articles were identified demonstrating that there is research and scientific production in this area. The thematic units and their categories are: treatment decision - prognostic scales or clinical neurological evaluation; types of treatment - minimally invasive and/or traditional; and effectiveness of prognostic scales higher or lower probability of success, which provide insight into the different possibilities of patient evaluation and their applicability in practice. When making the diagnosis, planning the treatment, and establishing a prognosis, the professional must be in sync with current precepts and act based on the objective and subjective characteristics of the patients, such as beliefs and values, which although immeasurable, influence the survival and the effectiveness of treatment. Level of evidence I; Integrative Review.
\end{abstract}

Keywords: Neoplasm Metastasis; Spine; Therapeutics; Prognosis.

\section{RESUMO}

Já que o atendimento ao paciente com metástases na coluna vertebral é desafiador, o presente artigo tem como propósito o tratamento e o prognóstico das metástases espinhais, visando enumerar e analisar literaturas que abordam o tratamento e o prognóstico. A metodologia utilizada consistia em uma revisão integrativa na Biblioteca Virtual de Saúde. Foram identificadas 19 literaturas demonstrando que há pesquisas e produções científicas nessa área, sendo que as unidades temáticas e suas categorias são: decisão quanto ao tratamento - escalas prognósticas ou avaliação clínica neurológica; tipos de tratamento - minimamente invasivos e ou tradicionais; efetividade das escalas de prognóstico - maior ou menor probabilidade de acerto; o que propicia vislumbrar as diferentes possibilidades de avaliação do paciente e sua aplicabilidade na prática. O profissional, ao realizar o diagnóstico, planejar o tratamento e estabelecer um prognóstico, deve estar em sincronia com os preceitos atuais e agir baseado nas características objetivas e nas subjetivas dos pacientes que, apesar de imensuráveis, como crenças e valores, influenciam na sobrevivência e na eficácia do tratamento. Nível de evidência I; Revisão Integrativa.

Descritores: Metástase Neoplásica; Coluna Vertebral; Terapêutica; Prognóstico.

\section{RESUMEN}

Ya que la atención al paciente con metástasis en la columna vertebral es desafiante, el presente artículo tiene como propósito el tratamiento y el pronóstico de las metástasis espinales, con el objetivo de enumerar y analizar literaturas que abordan el tratamiento y el pronóstico. La metodología utilizada consistía en una revisión integrativa en la Biblioteca Virtual de Salud. Se identificaron 19 literaturas demostrando que hay investigaciones y producciones científicas en esta área, siendo que las unidades temáticas y sus categorías son: decisión cuanto al tratamiento - escalas pronósticas o evaluación clínica neurológica; tipos de tratamiento - mínimamente invasivos y/o tradicionales; efectividad de las escalas de pronóstico - mayor o menor probabilidad de acierto; lo que propicia vislumbrar las diferentes posibilidades de evaluación del paciente y su aplicabilidad en la práctica. El profesional, al realizar el diagnóstico, planificar el tratamiento y establecer un pronóstico, debe estar en sincronía con los preceptos actuales y actuar basado en las características objetivas y en las subjetivas de los pacientes que, a pesar de inmensurables, como creencias y valores, influencian en la supervivencia y en la eficacia del tratamiento. Nivel de evidencia I; Revisión Integrativa

Descriptores: Metástasis de la Neoplasia; Columna Vertebral; Terapéutica; Pronóstico. 


\section{INTRODUCTION}

With the discovery of methods for early diagnosis and innovative treatments for cancer, there is a greater possibility of developing metastasis. About two thirds of primary cancer cases involve metastasis and the skeletal system is the third most commonly affected location. ${ }^{1-3}$ Spinal bone metastasis is present in $40 \%$ of patients with neoplasia and it can spread through hematogenous, cerebrospinal fluid, and lymphatic pathways or directly by proximity. Unfortunately, only $10 \%$ of patients present symptoms such as pain, bone fractures, spinal cord compression, and hypercalcemia, making early diagnosis difficult. ${ }^{1-10}$

Spinal metastasis treatments aim to reduce tumor mass, prevent neurological losses, and reduce pain, favoring survival and quality of life. It requires a multidisciplinary team because it is a multifaceted disease, with different characteristics according to origin, systemic impairment, degree of bone involvement, degree of neurological impairment, among other factors pertinent to the organism of each individual and to the availability of resources. ${ }^{8-12}$

Treatment is complex and is based on several multidisciplinary therapeutic algorithms, depending on tumor involvement, patient symptoms, and the performance status of the patient, and there is no clear consensus on the best way to treat spinal metastases..$^{8-12}$

The subject of this article is the treatment and prognosis of spinal metastases according to the literature, aiming to identify, enumerate, and analyze this treatment and the prognosis.

\section{METHODS}

This is an integrative review of the Virtual Health Library (VHL), a Brazilian database with recognized reliability and free access, with inclusion criteria using neoplasm metastasis, spine, therapy, prognosis, in the health science descriptors, in the period from 2012 to 2017, in Portuguese, English and Spanish. The exclusion criteria were inability to access, duplicate publications, other languages, outside of the timeframes, and articles not related to the theme. The Impact Factor (IF) of the literature found, as well as the Level of Evidence (LE) and the Degree of Recommendation (DR) of each article according to the classification of the Centre for Evidence-Based Medicine (CEBM) in the United Kingdom, were included in the analysis. ${ }^{13-17}$

\section{RESULTS}

The initial literature total was 178 articles, of which 19 remained after selection. (Table 1)

The 19 articles are from globally recognized periodicals with a predominance of original (74\%), research (10\%), review (10\%), and experience report (6\%) articles. There was a relative predominance of foreign periodicals (58\%) and the databases were MEDLINE Online Medical Literature Research and Analysis System of the National Library of Medicine of the United States of America (58\%) and LILACS- Latin American and Caribbean Health Sciences Literature database (42\%). The predominant IF value was less than 1 in $60 \%$

Table 1. Association between descriptors and literature found in $\mathrm{VHL}$ from $2012-2017$.

\begin{tabular}{c|c|c|c|c|c|c|c|c|c}
\hline & & & \multicolumn{5}{|c}{ year } \\
\cline { 4 - 8 } Descriptors & Total & Filter & Selection & $\mathbf{2 0 1 2}$ & $\mathbf{2 0 1 3}$ & $\mathbf{2 0 1 4}$ & $\mathbf{2 0 1 5}$ & $\mathbf{2 0 1 6}$ & $\mathbf{2 0 1 7}$ \\
\hline $\begin{array}{c}\text { Neoplastic } \\
\begin{array}{c}\text { metastasis } \\
\text { and spine and } \\
\text { therapeutic }\end{array}\end{array}$ & 99 & 13 & 8 & 1 & 5 & 1 & - & 1 & - \\
\hline $\begin{array}{c}\text { Neoplastic } \\
\text { metastasis } \\
\text { and spine and } \\
\text { prognostic }\end{array}$ & 79 & 22 & 11 & 1 & 1 & 5 & 3 & 1 & - \\
\hline \multicolumn{1}{c}{ Total } & 178 & 35 & 19 & 2 & 6 & 6 & 3 & 2 & - \\
\hline
\end{tabular}

of the literature, from 1 to 2.99 in $30 \%$ of the literature, and from 3 to 4.9 in $10 \%$ of the literature as shown in Table 2.

The validation of these articles is described in Table 3.

The thematic units and categories found are described in Table 4.

\section{DISCUSSION}

Analyzing the 19 articles found in the 2012 to 2017 timeframe, it was verified that scientific production about the treatment and prognosis of spinal metastases continued during those years, although there were no publications from 2017, perhaps because at the time of the study it was only the beginning of 2018.

The fact that the articles were included in recognized periodicals makes it possible to infer that there is a real concern for spinal metastases among professionals, as most of the periodicals represent medical societies from different countries dedicated to this area, and these periodicals constitute a space for the promotion of scientific and technical knowledge, and the incentive and investment in scientific and operational research towards continuous healthcare quality improvement must be constant. ${ }^{36-39}$

The predominance of original articles in the literature, followed by the publication of research, literature reviews, and experience reports confirms the investment of professionals in the analysis of spinal metastases, principally in the area of treatment and prognosis, in search of new alternatives that build new foundations for actions in the field of spinal metastases. In this sense, communication and dissemination are essential to scientific progress and they confer legitimacy and recognition for the development of tools and the implementation of competences. ${ }^{40}$

Most of the authors are neurosurgeons, some are professors and two are medical resident authors in this area, as well as radiotherapists and orthopedists, highlighting their concern with the growth and specificity of this area of medicine, which requires trained human resources committed to permanent education. ${ }^{41,42}$

In this sense, it is worth noting that medical specialties are more than a simple division of labor. They result from medical development, scientific progress, and the deepening of knowledge and they are fundamental for patient needs in clinical situations that demand technical capacity, in the intelligence and specific skills of the physician, and, in the case of spinal metastasis, multi-professional work is essential for accurate decision-making. ${ }^{43-45}$

The IF of the selected articles shows that all the periodicals are indexed at the Institute for Scientific Information (ISI), published in the Journal Citation Reports (JCR) and in Thomson Reuters, and are therefore recognized and published internationally. Although $60 \%$ have an IF score of less than 1 , it is important to note that IF is the most used bibliometric indicator at the international level. It receives criticism, since there is the possibility that scientific journals try to manipulate this impact factor through the incorporation of a greater number of systematic review articles, more cited than the others, or encouraging self-citations, in addition to the fact that there is generally a higher search rate for articles written in English, which may explain the lower IF of Brazilian publications. ${ }^{46}$

The literature found in the MEDLINE and LILACS databases has credibility because these sources are leaders in the areas of health and medicine and both provide bodies of data that are interrelated, that perpetuate dissemination, and that represent updated, reliable publications from the scientific community. ${ }^{47}$

Regarding the methodology of the articles, most involve reproducible, prospective or retrospective cohort studies, aiming to enable the reproduction of any reported phenomenon, a quality essential for scientific status, as well as studies of case series, reviews, and case and experience reports, which add benefits to current practices or suggest new directions by sharpening the interpretation of knowledge and learning. ${ }^{48,49}$

Regarding the Degree of Recommendation of the articles selected, with Grade A - 26\%, Grade B - 69\%, and Grade D - 5\%, the achievement of Grade A or B by most of them indicates that these articles have rigorous scientific proof to guide decision making, 
Table 2. Technical description of the selected literature.

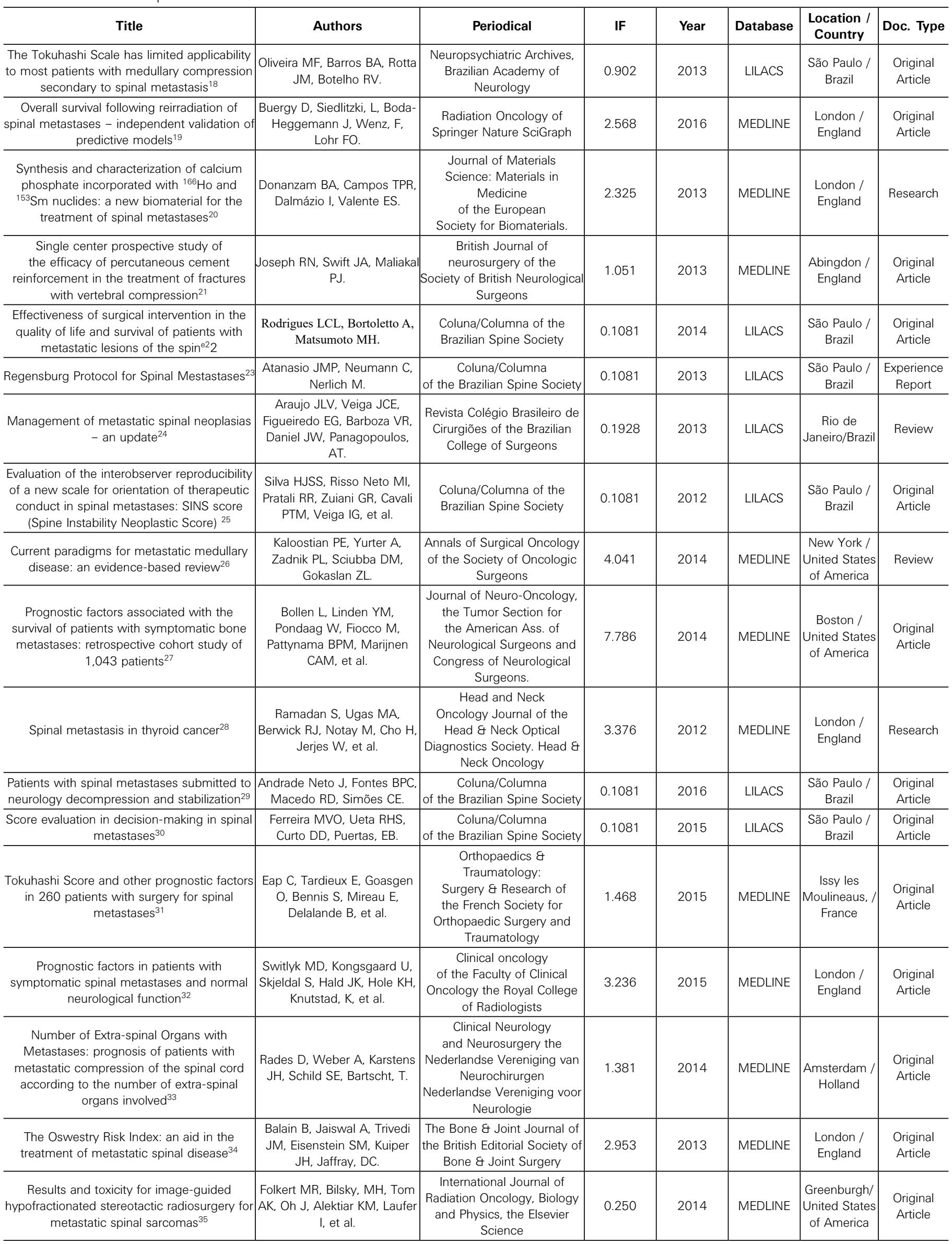


Table 3. Validation of the selected literature and the levels of evidence.

\begin{tabular}{|c|c|c|c|c|c|}
\hline Title & Objective(s) & Method & Evidence Data & LE & DR \\
\hline $\begin{array}{c}\text { The Tokuhashi Scale has limited } \\
\text { applicability to most patients with } \\
\text { medullary compression secondary } \\
\text { to spinal metastasis }\end{array}$ & $\begin{array}{c}\text { To evaluate the number of } \\
\text { completed Tokuhashi Scoring } \\
\text { System (TSS) until a therapeutic } \\
\text { decision is made }\end{array}$ & Case Series & \begin{tabular}{|c|} 
TSS survival prognosis requires time and technological and financial \\
resources. In urgent treatment of spinal metastases it is impossible to \\
fill out the TSS due to urgency. It was sustained that the criteria for a \\
surgical decision should be based on clinical and neurological disorders \\
instead of on prognostic scales.
\end{tabular} & $3 B$ & B \\
\hline $\begin{array}{c}\text { Overall survival following } \\
\text { reirradiation of spinal metastases } \\
\text { - independent validation of } \\
\text { predictive models }{ }^{19}\end{array}$ & $\begin{array}{c}\text { To validate the available survival } \\
\text { forecasting tools in a group of } \\
\text { patients submitted to reirradiation } \\
\text { of spinal metastases in a single } \\
\text { institution }\end{array}$ & Case Series & $\begin{array}{l}\text { The estimate of reirradiation survival used by the radio-oncologist: } \\
\text { primary tumor, central nervous system metastases, and general } \\
\text { metastatic load - little efficacy compared to SPT-Nieder that uses the } \\
\text { KPS-Karnofsky Performance Status index, liver metastases and steroid } \\
\text { use. SPT-Nieder higher prognostic precision, but the item pleural } \\
\text { effusion was not correlated in the study. }\end{array}$ & $3 \mathrm{~B}$ & B \\
\hline $\begin{array}{c}\text { Synthesis and characterization of } \\
\text { calcium phosphate incorporated } \\
\text { with }{ }^{166} \mathrm{Ho} \text { and }{ }^{153} \mathrm{Sm} \text { nuclides: a } \\
\text { new biomaterial for the treatment } \\
\text { of spinal metastases }\end{array}$ & $\begin{array}{l}\text { To summarize and characterize } \\
\text { bioceramics based on calcium } \\
\text { orthophosphates incorporated } \\
\text { with holmium }\left({ }^{166} \mathrm{Ho}\right) \text { and } \\
\text { samarium }\left({ }^{153} \mathrm{Sm}\right)\end{array}$ & $\begin{array}{l}\text { Non-living } \\
\text { experimental } \\
\text { model }\end{array}$ & $\begin{array}{l}\text { Radiovertebroplasty with use of radioactive bone cement, calcium } \\
\text { orthophosphate } \mathrm{Ho} / \mathrm{Sm} \text { bioceramics and computational dosimetry in } \\
\text { the }{ }^{166} \mathrm{Ho} \text { model. Therapeutic doses in the lesion less than } 10 \% \text { of } \\
\text { the normally used radiotherapy dose. I uphold that the treatment will } \\
\text { promote tumor control, less incidence of damage, and clinical studies } \\
\text { should be conducted to validate risks, benefits, and indications. }\end{array}$ & 5 & D \\
\hline $\begin{array}{l}\text { Single center prospective study } \\
\text { of the efficacy of percutaneous } \\
\text { cement reinforcement in the } \\
\text { treatment of fractures with } \\
\text { vertebral compression }{ }^{21}\end{array}$ & $\begin{array}{c}\text { To evaluate prospectively patients } \\
\text { with fractures with vertebral } \\
\text { compression using an } 11 \text {-point } \\
\text { visual analog scale for pain and } \\
\text { the Qualeffo- } 41 \text { quality of life } \\
\text { questionnaire }\end{array}$ & $\begin{array}{l}\text { Single center } \\
\text { prospective }\end{array}$ & $\begin{array}{c}\text { The use of percutaneous cement reinforcement is safe and effective } \\
\text { in the treatment of spinal fractures with painful compression related to } \\
\text { osteoporosis, trauma, and cancer, achieving rapid and significant pain } \\
\text { reduction and improved physical function, measured by a visual analog } \\
\text { scale and the Qualeffo- } 41 \text { questionnaire }\end{array}$ & $1 \mathrm{C}$ & A \\
\hline $\begin{array}{l}\text { Effectiveness of surgical } \\
\text { intervention in the quality of life } \\
\text { and survival of patients with } \\
\text { metastatic lesions of the spine }{ }^{22}\end{array}$ & $\begin{array}{l}\text { To evaluate the quality of life } \\
\text { of patients with metastatic } \\
\text { spinal lesions, observing pain, } \\
\text { neurological profile, and survival }\end{array}$ & Prospective & $\begin{array}{l}\text { Surgery does not influence patient survival, except in patients with } \\
\text { neurological deficit with poor prognosis. Treatment of the metastatic } \\
\text { lesion is many times palliative, but patients present neurological } \\
\text { improvement justifying surgical intervention. The neurological deficit } \\
\text { involves worsening of the prognosis }\end{array}$ & $2 C$ & B \\
\hline $\begin{array}{c}\text { Regensburg Protocol for Spinal } \\
\text { Mestastases }^{23}\end{array}$ & $\begin{array}{c}\text { To show the spinal metastasis } \\
\text { treatment protocol of the } \\
\text { University Hospital of Regensburg, } \\
\text { Germany. }\end{array}$ & $\begin{array}{l}\text { Experience } \\
\text { Report }\end{array}$ & $\begin{array}{c}\text { The Regensburg Protocol assesses spinal instability, neurological } \\
\text { deficit, survival greater than } 6 \text { months, possibility of resection of } \\
\text { the metastasis. If positive, perform embolization, resection of the } \\
\text { metastasis, implants for stabilization. If negative, percutaneous surgical } \\
\text { techniques only for pain control: vertebroplasty, kyphoplasty, or it is } \\
\text { not performed due to risk of death. Individualized surgical treatment: } \\
\text { conditions of the patients, neurological deficit, spinal instability, and } \\
\text { survival rate }\end{array}$ & $3 \mathrm{~B}$ & B \\
\hline $\begin{array}{c}\text { Management of metastatic spinal } \\
\text { neoplasias - an update }{ }^{24}\end{array}$ & $\begin{array}{l}\text { To find out about therapeutic } \\
\text { modalities in spinal metastasis }\end{array}$ & Literature Review & \begin{tabular}{|} 
Treatment of spinal metastasis should be individualized and \\
multidisciplinary: neurosurgeons, oncologists, oncologic surgeons, \\
radiotherapists, physiatrists, pain specialists, psychologist among others. \\
The rational choice of the therapeutic modality should be based on \\
the clinical and neurological condition of the patient, life expectancy, \\
degree of spinal impairment, histological type of the neoplasia, and \\
desire of the patient and the family.
\end{tabular} & $3 \mathrm{~A}$ & B \\
\hline $\begin{array}{c}\text { Evaluation of the interobserver } \\
\text { reproducibility of a new scale for } \\
\text { orientation of therapeutic conduct } \\
\text { in spinal metastases: SINS score } \\
\text { (Spine Instability Neoplastic } \\
\text { Score })^{25}\end{array}$ & $\begin{array}{l}\text { To evaluate the impact on } \\
\text { conduct and quantify the } \\
\text { interobserver reproducibility of } \\
\text { the SINS score. In addition, to } \\
\text { determine its applicability in our } \\
\text { environment. }\end{array}$ & $\begin{array}{l}\text { Retrospective } \\
\text { reproducibility } \\
\text { study }\end{array}$ & $\begin{array}{l}\text { The SINS is applicable in Brazil. Divergence between the evaluations in } \\
\text { terms of the stability of lesions before and after the application of SINS. } \\
\text { However, the therapeutic conduct was not modified for this new score. } \\
\text { The SINS has moderate interobserver reproducibility. }\end{array}$ & $1 \mathrm{~A}$ & A \\
\hline $\begin{array}{l}\text { Current paradigms for metastatic } \\
\text { medullary disease: an evidence- } \\
\text { based review }{ }^{26}\end{array}$ & $\begin{array}{l}\text { To review decision-making } \\
\text { strategies that determine the most } \\
\text { effective treatment options. }\end{array}$ & $\begin{array}{c}\text { Evidence-based } \\
\text { review }\end{array}$ & $\begin{array}{l}\text { Surgical oncology developing change in the management of surgical } \\
\text { patients with metastatic tumors. Greater vision: tumor biology, of the } \\
\text { surgical approaches, oncology by radiation instrumentation, stereotactic } \\
\text { radiosurgery, and intensity-modulated radiation therapy }\end{array}$ & $3 \mathrm{~A}$ & B \\
\hline $\begin{array}{c}\text { Prognostic factors associated } \\
\text { with the survival of patients with } \\
\text { symptomatic bone metastases: } \\
\text { retrospective cohort study of } \\
1,043 \text { patients }^{27}\end{array}$ & \begin{tabular}{|c|} 
To identify prognostic factors \\
associated with survival in patients \\
with symptomatic SBM and to \\
create a validated risk stratification \\
model.
\end{tabular} & $\begin{array}{l}\text { Retrospective } \\
\text { single center } \\
\text { cohort }\end{array}$ & $\begin{array}{l}\text { The Frankel scale: not for spinal metastases. Created three-variable } \\
\text { flowchart - clinical profile; KPS index, visceral and/or cerebral } \\
\text { metastases, their marked use favorable clinical patient profile. Use } \\
\text { flowchart comparing efficiency of treatment modalities, radiotherapy } \\
\text { center, and quality of life } \\
\end{array}$ & $1 \mathrm{C}$ & A \\
\hline $\begin{array}{l}\text { Spinal metastasis in thyroid } \\
\text { cancer }^{28}\end{array}$ & $\begin{array}{c}\text { To analyze management options } \\
\text { proposed in the literature and } \\
\text { the recommendations that can } \\
\text { improve the prognosis of patients } \\
\text { with spinal metastases of thyroid } \\
\text { carcinomas. }\end{array}$ & $\begin{array}{c}\text { Systematic } \\
\text { literature review }\end{array}$ & $\begin{array}{c}\text { Administer radioiodine I-131 \& surgery. Associate SET (selective } \\
\text { embolization therapy), bisphosphonates, VEGFR (vascular endothelial } \\
\text { growth factor receptors) inhibitors. Young patient surgery: radiotherapy } \\
\text { verify SET or cytotoxic chemotherapy. VEGFR useful non-aggressive } \\
\text { disease, bisphosphonate palliation / SET. Necessary studies on the } \\
\text { combination of therapies. Ideal future interception in the molecular } \\
\text { pathways of the tumor genes to prevent dissemination. Current surgery } \\
\text { more logical - but not curative, palliative }\end{array}$ & $3 \mathrm{~A}$ & B \\
\hline $\begin{array}{l}\text { Patients with spinal metastases } \\
\text { submitted to neurology } \\
\text { decompression and stabilization }\end{array}$ & $\begin{array}{c}\text { To analyze surgery of metastases, } \\
\text { arthrodesis / pedicle screws via } \\
\text { isolated posterior approach. }\end{array}$ & $\begin{array}{l}\text { Retrospective / } \\
\text { case series }\end{array}$ & $\begin{array}{c}\text { Surgery through arthrodesis / pedicular instrumentation / } \\
\text { decompression brings significant clinical benefits, improved pain and } \\
\text { neurological profiles. }\end{array}$ & $3 B$ & B \\
\hline
\end{tabular}




\begin{tabular}{|c|c|c|c|c|c|}
\hline Title & Objective(s) & Method & Evidence Data & LE & DR \\
\hline $\begin{array}{l}\text { Score evaluation in decision- } \\
\text { making in spinal metastases }\end{array}$ & $\begin{array}{l}\text { To evaluate the intra- and } \\
\text { interobserver concordance of the } \\
\text { SINS, Harrington, Tokuhashi, and } \\
\text { Tomita scores. }\end{array}$ & $\begin{array}{l}\text { Retrospective } \\
\text { reproducibility } \\
\quad \text { study }\end{array}$ & $\begin{array}{c}\text { Predictive instability scores - Harrington, prognostic - Tomita, have } \\
\text { higher intra- and interobserver reliability among spinal surgeons with } \\
\text { more than } 10 \text { years of experience. The SINS score - election for daily } \\
\text { practice and the most frequent capable of modifying the conduct. }\end{array}$ & $1 \mathrm{~A}$ & A \\
\hline $\begin{array}{l}\text { Effectiveness of surgical } \\
\text { intervention in the quality of life and } \\
\text { survival of patients with metastatic } \\
\text { lesions of the spine. } .^{22}\end{array}$ & $\begin{array}{c}\text { To evaluate the impact of the } \\
\text { surgical treatment of spinal epidural } \\
\text { metastatic lesions on the quality of } \\
\text { life, pain improvement, and survival } \\
\text { of the patients }\end{array}$ & $\begin{array}{l}\text { Prospective } \\
\text { observational }\end{array}$ & $\begin{array}{c}\text { Used the Oswestry questionnaire, the Frankel et al. Scale, Tokuhashi } \\
\text { score, VAS score, criteria of Panjabi et al., Kostuik criteria. Concluded } \\
\text { early diagnosis of spinal metastases through action of multidisciplinary } \\
\text { team, pain must be valued especially with weight loss and progressive } \\
\text { worsening. Surgery depends on clinical conditions, degree of instability, } \\
\text { and tumor location. The surgery does not influence patient survival, } \\
\text { except in neurological deficit. Surgery is palliative - less pain and neural } \\
\text { protection }\end{array}$ & $1 \mathrm{C}$ & A \\
\hline $\begin{array}{l}\text { Tokuhashi Score and other } \\
\text { prognostic factors in } 260 \\
\text { patients with surgery for spinal } \\
\text { metastases }\end{array}$ & $\begin{array}{c}\text { To evaluate the performance of } \\
\text { the Tokuhashi score in a cohort } \\
\text { of } 260 \text { patients and to look for } \\
\text { other variables that can improve } \\
\text { the forecasting of results prior to } \\
\text { surgery. }\end{array}$ & $\begin{array}{l}\text { Retrospective } \\
\text { single center } \\
\text { cohort }\end{array}$ & $\begin{array}{l}\text { It supports the validity and reproducibility of Tokuhashi. Our discovery } \\
\text { that less time for the diagnosis of metastases and age } \geq 70 \text { year also } \\
\text { were significantly associated with survival in our populations; suggests } \\
\text { additional effort to improve and update the Tokuhashi score. }\end{array}$ & $2 \mathrm{~B}$ & B \\
\hline $\begin{array}{l}\text { Prognostic factors in patients with } \\
\text { symptomatic spinal metastases } \\
\text { and normal neurological function } \\
\end{array}$ & $\begin{array}{l}\text { To evaluate potential prognostic } \\
\text { factors to predict survival after } \\
\text { radiotherapy in patients with } \\
\text { painful spinal metastases and } \\
\text { normal neurological function. }\end{array}$ & Cohort study & $\begin{array}{c}\text { Predictive factors: primary cancer site, KPS, albumin level, number of } \\
\text { visceral metastases, and analgesic use. The pretreatment albumin level } \\
\text { is an important predictor in calculating the survival rate and determining } \\
\text { treatment. Use of analgesics at the onset of treatment significant factor } \\
\text { in results as well as chemotherapy use. Multivariate analysis may make } \\
\text { the scoring more universal and suitable for all patients with metastases, } \\
\text { regardless of treatment received. }\end{array}$ & $2 \mathrm{~B}$ & B \\
\hline $\begin{array}{l}\text { Number of Extra-spinal Organs } \\
\text { with Metastases: prognosis } \\
\text { of patients with metastatic } \\
\text { compression of the spinal cord } \\
\text { according to the number of extra- } \\
\text { spinal organs involved }\end{array}$ & $\begin{array}{l}\text { To investigate the survival } \\
\text { prognosis of patients with } \\
\text { metastatic spinal cord } \\
\text { compression (MSCC) with extra- } \\
\text { spinal involvement }\end{array}$ & $\begin{array}{l}\text { Retrospective } \\
\text { cohort }\end{array}$ & $\begin{array}{c}\text { Eight prognostic factors were investigated: age, sex, ECOG (Eastern } \\
\text { Cooperative Oncology Group) performance status, primary tumor type, } \\
\text { number of vertebrae involved, interval between cancer diagnosis and } \\
\text { Radiotherapy (RT), pre-RT clinical status, and time to development of } \\
\text { motor deficits. New studies are recommended. The number of extra- } \\
\text { spinal organs with metastases is an independent prognostic factor for } \\
\text { the survival of MSCC patients. }\end{array}$ & $2 \mathrm{~B}$ & B \\
\hline $\begin{array}{l}\text { The Oswestry Risk Index: an aid in } \\
\text { the treatment of metastatic spinal } \\
\text { disease }\end{array}$ & $\begin{array}{l}\text { To verify whether the Oswestry } \\
\text { Risk Index is applicable to spinal } \\
\text { metastatic disease }\end{array}$ & $\begin{array}{l}\text { Prospective } \\
\text { cohort }\end{array}$ & $\begin{array}{c}\text { Tokuhashi, Tomita, and Bauer exhaustive. The Oswestry Spinal Risk } \\
\text { Index (OSRI), simple summation of two elements: primary tumor } \\
\text { pathology (PTP) and general condition (GC): OSRI = PTP }+(2-\mathrm{GC}) \text {, } \\
\text { simple point system predicts life expectancy and may be useful in the } \\
\text { treatment of spinal metastasis. }\end{array}$ & $2 \mathrm{~B}$ & B \\
\hline $\begin{array}{l}\text { Results and toxicity for image- } \\
\text { guided hypofractionated } \\
\text { stereotactic radiosurgery for } \\
\text { metastatic spinal sarcomas }\end{array}$ & \begin{tabular}{|} 
To investigate whether \\
hypofractionated (HF) or single \\
fraction (SF) image-guided \\
stereotactic radiosurgery (IG-SRS) \\
can effectively control the lesions.
\end{tabular} & $\begin{array}{l}\text { Retrospective } \\
\text { cohort }\end{array}$ & $\begin{array}{l}\text { In most of series of metastatic spinal sarcomas of the study image- } \\
\text { guided single fraction stereotactic radiosurgery demonstrated minimal } \\
\text { toxicity and excellent local control. }\end{array}$ & $2 \mathrm{~B}$ & B \\
\hline
\end{tabular}

summarizing the research available on the treatment and prognosis of spinal metastasis. The only article with Recommendation Grade $D$ deals with a bold proposal yet untested in humans and equally important to the production of knowledge. ${ }^{50,51}$

The categories "prognostic scales and/or clinical evaluation scales" in the "treatment decision" thematic unit highlight that professionals should ally the scales with the institutional resources, the professional experience, and above all with the holistic view of the patient, with their acquiescence to treatment and the tangible benefits of that treatment for the patients. This finding agrees with other scholars who affirm that treatment should not be based solely on scales, but also on the individual characteristics of each patient. ${ }^{52,53}$

The scales discussed in the articles selected are the KPS classification, the original or adapted scores of Frankel, Harrington, Tomita, Tokuhashi, Bauer, Chow, Enneking, ECOG, the criteria of Panjabi et al., the criteria of Kostuik, the spinal instability neoplastic score (SINS), the LANSS pain scale and/or the visual analog scale (VAS) for pain, and the original survival prediction tool (SPT) or that envisioned by Nieder. ${ }^{19,22,27,30-32,35}$

In addition to these scales, there are others that can be used in the evaluation of patients with spinal metastases, adding more detailed aspects and with a multidisciplinary view of the patient centered on functional capacity, functional independence/physical performance, on the presence of comorbidities, the quality of life and satisfaction, on the presence of depression and mood disorders, on functional activity to return to work, but, due to Brazilian sociocultural peculiarities, the results may not be fully applicable in their entirety. ${ }^{19,25,54-68}$
Another aspect to be mentioned is that a decision centered only on prognostic scales can often produce inhuman situations for the patients and their families, characterizing for them a feeling of abandonment and discredit. In one study, patients who scored between 0 and 8 on the modified Tokuhashi scale and who normally would not have been operated on because of poor prognosis, underwent surgery and had a longer survival than expected from the score, showing the benefit of investing in patients with worse prognoses. ${ }^{64}$

In this context, despite the numerous scales available to assist with therapeutic indications and their validity in determining the prognosis in treatment of spinal metastasis, a multidisciplinary team is essential to evaluate individual patient factors that go beyond the physical area, such as functional performance, neurological deficit, spinal instability, psychological and emotional state, involving their uniqueness, their values, and their beliefs. ${ }^{66,67,69-71}$

The thematic unit "types of treatment" in spinal metastases includes the minimally invasive and traditional categories, the former being predominantly cited.

The treatment is associated with the diagnosis of the spinal metastases with the investigation of the symptoms present in $10 \%$ of patients:

- Pain: In 83-95\% of the patients, pain precedes the development of other neurological symptoms by weeks or months. Localized pain is the result of intrabone pressure and, with the evolution of bone changes, pain is precipitated by movement (mechanical pain) or involves the nerve endings through compression of the spinal cord causing the often acute pain that follows the path of the compromised nerve 
Table 4. Literature by Thematic Unit and Categories.

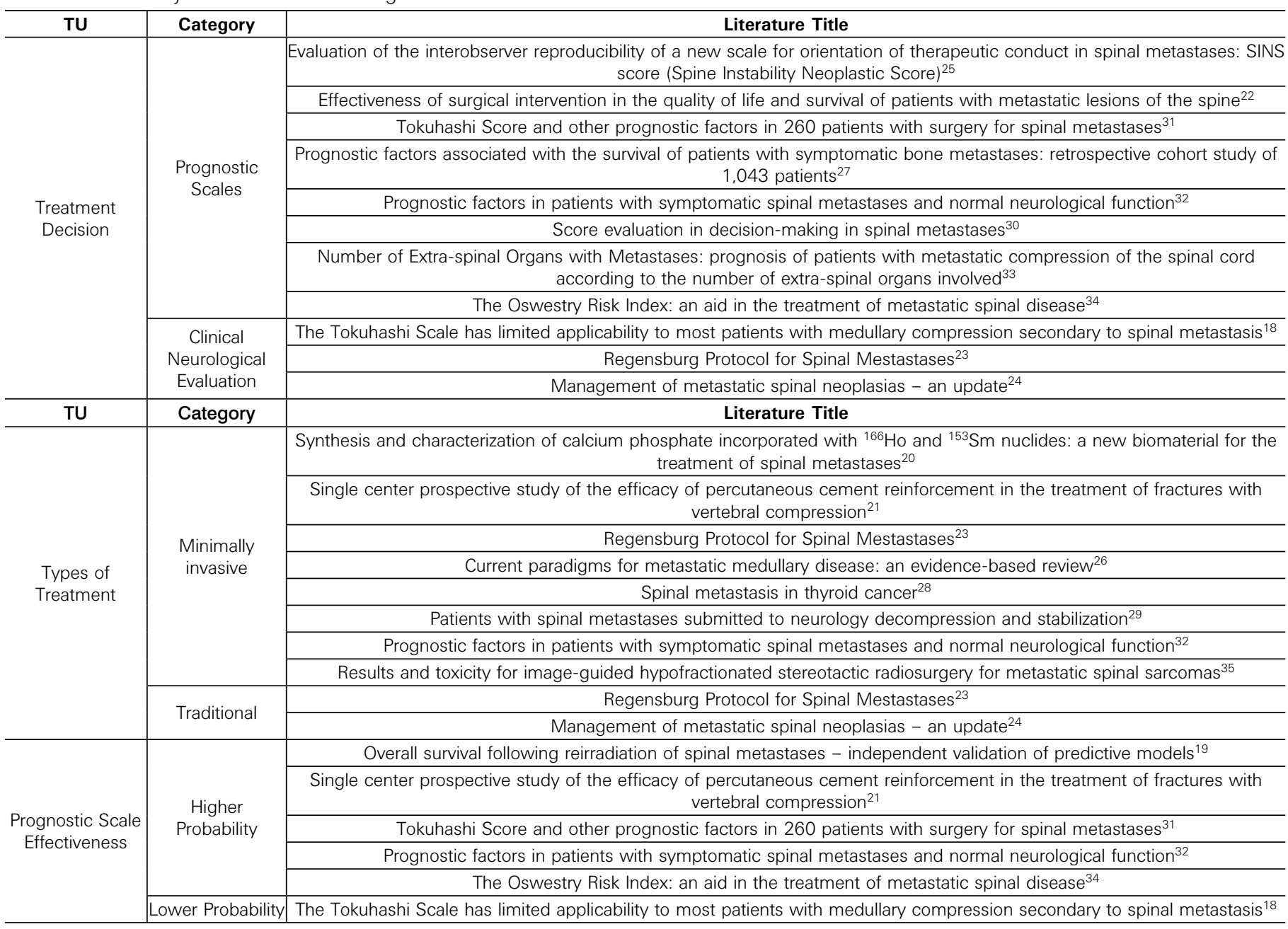

root (radicular pain), in addition to the possibility of referred pain in a location distant from the metastases in cases of lumbar spinal cord compression. For localized pain, non-steroidal or steroidal anti-inflammatories are used. For radicular pain, interlaminar or transforaminal epidural steroid injections are usually applied. In mechanical pain, it recommended to stabilize the spine as conventional or minimally invasive arthrodesis, vertebroplasty, kyphoplasty, stereotactic radiosurgery or surgery traditional as vertebrectom. 7,29,72-84

- Fracture: Sometimes fractures are the first symptom associated with pain. The thoracolumbar region is the most frequent site of spinal fractures. The treatment can be radiotherapy, conventional or minimally invasive arthrodesis, vertebroplasty, kyphoplasty, stereotactic radiosurgery or traditional surgery. ${ }^{85-90}$

- Spinal cord compression: 5 to $10 \%$ of patients have spinal cord compression. Usually there is a report of lumbar or cervical pain, paresthesia, loss of physical strength in the area of the body below the tumor, difficulties with mobility of the upper or lower limbs depending on its location leading to paraplegia or quadriplegia, and difficulties with urinary (incontinence or retention) and intestinal (fecal incontinence) function. It demands immediate attention through the administration of corticosteroids, radiopharmaceuticals, or radiotherapy. Decompression surgery is indicated when the affected area was previously submitted to unsuccessful radiotherapy or when there was neurological deterioration during the radiotherapy procedure, and when the spine is unstable and there are not multiple zones of compression, vertebroplasty, kyphoplasty, or stereotactic radiosurgery can be performed. ${ }^{72,78-81}$

- Hypercalcemia is present in 20 to $44 \%$ of patients (release of calcium from bone destruction), characterized by the progressive decline of cognitive ability, stupor, and coma, as well as polyuria, anorexia, nausea, and vomiting, which undiagnosed can lead to death. Treatment is essential to providing the patient the possibility of undergoing treatment directed at the neoplasia. Calcium should be avoided whether in parenteral nutrition or present in medications, sedatives should be reduced to improve the level of consciousness, and hydration and expansion of circulating volume should be achieved. Other treatments include phosphate repositioning, administration of glucocorticoids to reduce intestinal absorption, and antiresorptive medications, such as bisphosphonates like zoledronic acid. ${ }^{73,82-85}$

The diagnosis should also be conducted using imaging exams, such as X-rays, magnetic fields, or radioactive substances. The X-ray can show signs of dissemination of the disease to the bones in osteolytic or lytic metastases, due to destruction of the bone. Osteoblastic or blastic metastases appear as darker gray-white areas in the bone image, because due to the non-reabsorption of bone the area of bone appears denser. X-rays can also show fractures in bones weakened by metastases. Bone scintigraphy shows the presence (or not) of bone metastases, as areas of bone damage appear as dark spots in the image of the skeleton. In addition to these, there are computed tomography and/or magnetic resonance with and without contrast, positron emission tomography or PET scan, which enables detection of whether the cancer has spread to the lymph nodes or to other body structures and organs, and also needle or incisional biopsy, and laboratory tests of tumor markers, calcium and alkaline phosphatase, and $\mathrm{N}$-telopeptide (urine). ${ }^{82-86}$

The predominance of articles in the literature on minimally invasive surgical procedures in the treatment of spinal metastases agrees 
with the current trends that also consider this treatment the most appropriate for local control of the disease, improved performance and neurological function, and pain control, with minimal possibility of morbidity. 4,69,75,79,87,90,91

The most commonly used minimally invasive techniques are vertebroplasty, kyphoplasty, and stereotactic radiosurgery. Vertebroplasty consists of a percutaneous injection of fast-fixing bone cement inside the vertebral body, whereas kyphoplasty involves the prior dilatation of the collapsed vertebral body to form a cavity that allows the introduction of the cement with gradual pressure. These procedures are performed under the guidance of radioscopy or computed tomography. These techniques successfully stabilize the vertebral body with pain relief in $75 \%$ to $85 \%$ of patients. ${ }^{24,73,74,92,93}$

Stereotactic radiosurgery (SRS) of the bone is an emerging technique that involves the administration of high doses of radiation to a given region, in a single treatment fraction or in a few fractions, and is a safe and effective treatment modality for small, well-defined tumors, in addition to having advantages for the patient of low toxicity risk, and reduction of the number of visits for treatment and the associated costs. It involves a specific multidisciplinary decision for each patient, especially with radio-resistant tumors like sarcoma, melanoma, renal cell carcinoma, non-small-cell lung cancer, and carcinoma of the colon. ${ }^{93-97}$

Another aspect to be considered in the treatment of spinal metastases is the protocol of the North American hospital, the Memorial Sloan-Kettering Cancer Center, used to determine the ideal therapy for patients based on four fundamental evaluations: Neurological, Oncological, Mechanical Stability, and Systemic Disease (NOMS), not cited in the articles selected for this study. ${ }^{98}$

In the neurological aspect of NOMS, the presence of neurological deficit with signs of myelopathy and radiculopathy and the degree of spinal cord compression are evaluated. In the oncological area, the characteristics of the tumor and its susceptibility to radiotherapy are studied. In mechanical instability, the SINS is used, and the presence of fractures is verified in order to consider the need for vertebroplasty, kyphoplasty, or traditional surgery. The systemic aspect seeks to identify the extent of the disease and comorbidities, verifying tolerance to treatment. Thus, the expected overall survival of the patient is based on the extent of the disease and the histology of the tumor. ${ }^{98,99}$

The objective of NOMS is to provide a dynamic infrastructure for the treatment of spinal metastases with the ability to incorporate advances in interventionist radiology, radiation, medical oncology, and surgical techniques to optimize patient outcomes. In addition, NOMS provides a single language for all the professionals, since as these treatment decisions become more complex,

\section{REFERENCES}

1. WHO 2011. Global status report on non-communicable diseases 2010. Geneva: World health Organization, 2011. [acesso 21 de jan 2018]. Disponível: www.who. int/cancer.

2. ONUBR - Nações Unidas do Brasil. OMS: câncer mata 8,8 milhões de pessoas anualmente no mundo. Nações Unidas do Brasil. Publicado 03/02/2017. [acesso 21 de jan 2018]. Disponível: https://nacoesunidas.org/oms-cancer-mata-88-milhoes-de-pessoas-anualmente-no-mundo/

3. Lee CS, Jung CH. Metastatic Spinal Tumor. Asian Spine J.( Uijeongbu). 2012;6(1):71-87.

4. Joaquim AF, Ghizoni E, Tedeschi H, Pereira EB, Giacomin LA. Radiocirurgia estereotáxica para metástases de coluna vertebral: revisão de literatura. Einstein (São Paulo) 2013:11(2):247-55

5. Knoeller SM, Huwert O, Wolter T. Single stage corpectomy and instrumentation in the treatment of pathological fractures in the lumbar spine. Clin Orthop Relat Res. 2013:471(3):947-55

6. Sabas CV, Brito LXE, Soares LFM, Rodrigues JMR, Lustosa AML, Barbosa CNB, et al. Oncologia Básica. $1^{\text {a }}$ Ed. Teresina, Pl: Fundação Quixote; 2012

7. Costa J, Andrade A, Martins J, Berhanu N, Rodrigues J. Tratamento das metástases vertebrais. Rev Port Ortop Traum. (Lisboa). 2014;22(4):350-9.

8. Brasil AVB. Metástases na coluna vertebral. Coluna/Columna (São Paulo). 2010;9(2):VIII.

9. Araújo JLV, Veiga JCE, Figueiredo EG, Barboza VR, Daniel JW; Panagopoulos AT. Manejo das neoplasias metastáticas da coluna vertebral- uma atualização. Rev Col Bras Cir (Rio de Janeiro). 2013:40(6):508-14

10. Manca A, Ambrósio LD, Chiara G, Gatti M, Marone S, Salatino A, et al. Multidisciplinary managent of vertebral metastases in patients not amenable to surgery. Cancer Breaking News. (Milão). 2016; 4:23-33. an evidence-based, multidisciplinary approach, including oncologists, physicians, radiation oncologists, surgeons, interventionists, and pain specialists is necessary. ${ }^{97,98}$

Regarding the thematic unit "prognostic scale effectiveness", in the articles found there is a predominantly greater probability that these scales indicate the survival of patients with bone metastases more accurately, even though they are many times exhaustive because they involve various measures and time availability, which led one of the articles to advise against the use of scales. ${ }^{97-99}$

However, the use of scales is useful and essential as it often helps professionals to broaden their ability to predict cancer patient survival, although this expectancy is relative and may be lengthened or shortened, regardless of the clinical experience of the professional or the overall knowledge about the patient. ${ }^{100}$

\section{CONCLUSION}

By conducting this study, it was possible to identify, enumerate, and analyze articles that address the treatment and prognosis of spinal metastases. The fact that there were 19 articles shows that there is research and scientific production in this area. The thematic units and their categories, treatment decision - prognostic scales or clinical neurological evaluation, types of treatment - minimally invasive or traditional, and prognostic scale effectiveness, provide insight into the different possibilities for patient assessment and their applicability in practice.

When making the diagnosis, planning the treatment, and establishing a prognosis, the professional should be aware and deliberate actions based on the objective and the essentially subjective characteristics of the patients, such as beliefs and values, which though immeasurable, influence survival and the efficacy of the treatment.

This study leads to reflection about the treatment of spinal metastases, shedding light on scientific production. The decision about treatment should be based individually on the understanding of each surgeon and of the clinical situation of each patient and the greater the knowledge acquired, the lower the risk and the greater the benefits for the patient, affecting the positive prognosis.

It is up to the professional to care for these patients with optimism and determination, understanding that cancer and its metastases may involve finitude, but it is common for all human beings and should be experienced with dignity, comfort, and respect.

All authors declare no potential conflict of interest related to this article.
11. Shah LM, Salzman KL. Imaging of Spinal Metastatic Disease. Int J Surg Oncol. 2011:2011:769753.

12. Choi D, Bilsky M, Feblings $M$, Fisher $C$, Gokaslan Z. Spine Oncology-Metastatic Spine Tumors. Neurosurgery. 2017;80(3S):S131-7.

13. Botelho LLR, Cunha CC, Macedo M. O método da revisão integrativa nos estudos organizacionais. Gestão e Sociedade (Belo Horizonte). 2011;5(11):121-36.

14. Testa J. A base de dados ISI e seu processo de seleção de revistas. Ci Inf. (Brasília). $1998 ; 27(2): 233-5$.

15. Portugal MJ, Branca S, Rodrigues M. Dados de medida de fator de impacto das revistas científicas. Rev Enf Ref. 2011; ser III(5):211-5.

16. OCEBM Levels of Evidence Working Group. "The Oxford 2011 Levels of Evidence". Oxford Centre for Evidence-Based Medicine; 2011. [acesso 22 de jan 2018]. Disponível: https:// www.cebm.net/wp-content/uploads/2014/06/CEBM-Levels-of-Evidence-2.1.pdf

17. Carlomagno MC, Rocha LC. Como criar e classificar categorias para fazer análise de conteúdo: uma questão metodológica. Revista Eletrônica de Ciência Política. 2016;7(1):173-88.

18. Oliveira MF, Barros BA, Rotta JM, Botelho RV. A Tokuhashi Scoring System has limited applicability in the majority of patients with spinal cord compression secondary to vertebral metastasis. Arq Neuro-Psiquiatr. 2013;71(10):798-801.

19. Buergy D, Siedlitzki L, Boda-Heggemann J, Wenz F, Lohr F. Overall survival after reirradiation of spinal metastases - independent validation of predictive models. Radiat Oncol. 2016;11:35.

20. Donanzam BA, Campos TPR, Dalmázio I, Valente ES. Synthesis and characterization of calcium phosphate loaded with $\mathrm{Ho}^{-166}$ and $\mathrm{Sm}^{-153}$ : a novel biomaterial for treatment of spine metastases. J Mater Sci Mater Med. 2013;24(12):2873-80.

21. Joseph RN, Swift JAJ, Maliakal PJ. Single centre prospective study of the efficacy of per- 
cutaneous cement augmentation in the treatment of vertebral compression fractures. $\mathrm{Br} \mathrm{J}$ Neurosurg. 2013;27(4):459-64.

22. Rodrigues $\mathrm{LCL}$, Bortoletto $\mathrm{A}$, Matsumoto $\mathrm{MH}$. Efetividade da intervenção cirúrgica na qualidade de vida e na sobrevida dos pacientes com lesões metastáticas na coluna vertebral. Coluna/Columna. 2014;13(1):57-62.

23. Atanásio JMP, Neumann C, Nerlich M. Protocolo de Regensburg para Metástases da Coluna. Coluna/Columna. 2013;12(4):334-6.

24. Araujo, João L V; Veiga, José C E; Figueiredo, Eberval G; Barboza, Victor R; Daniel, Jefferson W; Panagopoulos, Alexandros T. Manejo das neoplasias metastáticas da coluna vertebral - uma atualização. Rev Colégio Brasileiro Cirurgiões; 2013, nov.-dez. [ 31 de jan 2018], 40(6): 508-514. Disponível: http://www.scielo.br/scielo.php?script=sci_arttex tepid=S0100-69912013000600015.

25. Silva HJSS, Risso Neto MI, Pratali RR, Zuiani GR, Cavali PTM, Veiga IG, et al. Avaliação da reprodutibilidade interobservadores de uma nova escala para orientação da conduta terapêutica nas metástases vertebrais: escore SINS (Spine Instability Neoplastic Score). Coluna/Columna. 2012;11(4):287-9

26. Kaloostian PE, Yurter ALP, Zadnik PL, Sciubba DM, Gokaslan ZL. Current paradigms for metastatic spinal disease: an evidence-based review. Ann Surg Oncol. 2014;21(1):248-62.

27. Bollen L, Linden YM, Pondaag W, Fiocco M, Pattynama BPM, Marijnen CAM, et al. Prognostic factors associated with survival in patients with symptomatic spinal bone metastases: a retrospective cohort study of 1,043 patients. J Neuro Oncol. 2014;16(7):991-8.

28. Ramadan S, Ugas MA, Berwick RJ, Notay M, Cho H, Jerjes W, et al. Spinal metastasis in thyroid cancer. Head Neck Oncol. 2012:4:39,

29. Andrade Neto J, Fontes BPC, Macedo RD, Simões CE. Pacientes com metástases na coluna vertebral submetidos à descompressão neurológica e estabilização. Coluna/ Columna. 2016;15(3):230-4.

30. Ferreira MVO, Ueta RHS, Curto DD, Puertas EB. Avaliação de Escores na tomada de decisão em metástases na coluna. Coluna/Columna. 2015;14(4):312-6.

31. Eap C, Tardieux E, Goasgen O, Bennis S, Mireau E, Delalande B, et al. Pontuação de Tokuhashi e outros fatores prognósticos em 260 pacientes com cirurgia para metástases vertebrais. Orthop Traumatol Surg Res. 2015; 101(4):483-8.

32. Switlyk MD, Kongsgaard ULF, Skjeldal S, Hald JK, Hole KH, Knutstad K, et al. O Prognostic factors in patients with symptomatic spinal metastases and normal neurological function. Clin Oncol (R Coll Radiol). 2015;27(4):213-21.

33. Rades DWA, Karstens JH, Schild SE, Bartscht T. Prognostic role of the number of involved extraspinal organs in patients with metastatic spinal cord compression. Clin Neurol Neurosurg. 2014:118:12-5

34. Balain B, Jaiswal A, Trivedi JM, Eisenstein SM, Kuiper JH, Jaffray DC. The Oswestry Risk Index: an aid in the treatment of metastatic disease of the spine. Bone Joint J. 2013;95$B(2) \cdot 210-6$

35. Folkert MR, Bilsky MH, Tom AK, Oh JH, Alektiar KM, Laufer I, et al. Outcomes and toxicity for hypofractionated and single-fraction image-guided stereotactic radiosurgery for sarcomas metastasizing to the spine. Int J Radiat Oncol Biol Phys. 2014:88(5):1085-91.

36. Fagundes, Renato B. Qual a missão das Sociedades Médicas. Revista da AMRIGS, Porto Alegre, 2018, 2008 jul-set [acesso 23 jan. 2018], 52(3): 157. Disponível: http://www. amrigs.org.br/revista/52-03/05-editorial.pdf.

37. Garcia JEMV Visco MALL, Bernardes RC. Pan J. Escritório de Projetos Aplicado à PD\&l: O Caso do Hospital Albert Einstein. Revista Eletrônica Gestão \& Saúde. 2013;4(03):1063-83.

38. Cavalieri VA, Figueiredo EG, Teixeira MJ. Liga de Neurocirurgia, uma experiência de vinte anos. Rev Med (São Paulo). 2016;95(1):30-2.

39. Santos IMG Influência do grau de especialização médica no diagnóstico de freturas vertebrais benignas e malignas nas imagens de ressonância magnética. Dissertação Mestrado Ciências das Imagens e Física Médica. Faculdade de Medicina de Ribeirão Preto da Universidade de São Paulo. 2015. Disponível em: http://www.teses.usp. br/teses/disponiveis/17/17158/tde-17042018-154321/pt-br.php

40. Droescher FD, Silva EL. O pesquisador e a produção científica. Perspect Ciênc Inf. 2014:19(1):170-89.

41. Isolan GR. A construção do conhecimento pelo jovem neurocirurgião: ética, ciência e a importância do treinamento em laboratório de microcirurgia. J Bras Neurocirurg. 2009:20(3):314-34

42. Leite NM, Falopa F. Propedêutica Ortopédica e Traumatológica. Porto Alegre: Artmed Editora; 2013

43. Farias QLT, Rocha SP, Cavalcante ASP, Diniz JL, Postes Neto OA, Vasconcelos MIO. Implicacões das tecnologias de informação e comunicação no processo de educação permanente em saúde. Rev Eletron Comun Inf Inov Saúde. 2017;1(4):1-11.

44. Rego S. O Profissionalismo e a Formação médica. Rev Bras Educ Med. 2012;36(4):445-6.

45. Bacheschi LA. Especialidades médicas: a importância do registro nos Conselhos de Medicina. Jornal do CREMESP. 2010 [acesso 23 fev. 2018];276:2. Disponível: https://www. cremesp.org.br/?siteAcao=Jornal\&id=1365

46. Portugal MJ, Branca S, Rodrigues M. Dados de medida de fator de impacto das revistas científicas. Rev Enf Ref. 2011;serlll(5):211-5.

47. Pereira MM, Sá MAB, Oliveira SKM, Freitas DA. Utilização de bases de dados bibliográficas. EFDeportes.com, Revista Digital. Buenos Aires. 2013 [acesso 23 fev. 2018]; 17(178). Disponível: http://www.efdeportes.com/efd178/utilizacao-de-bases-de-dados-bibliograficas.htm

48. Oliveira MAP, Parente RCM. Estudos de Coorte e de Caso-Controle na Era da Medicina Baseada em Evidência. Bras J Video-Sur. 2010:3(3):115-25

49. Nassi-Calò L. Reprodutibilidade em resultados de pesquisa: os desafios da atribuição de confiabilidade. Scielo em Perspectiva. 2016. [acesso 23 fev. 2018]. Disponível: http://blog.scielo.org/blog/2016/03/31/reprodutibilidade-em-resultados-de-pesquisa-os-desafios-da-atribuicao-de-confiabilidade/\#.WpFxxPxG3cc

50. Atallah ÁN. Medicina Baseada em Evidências: o elo entre a boa ciência e a boa prática clínica. In: Atallah ÁN, Castro AA. Medicina Baseada em Evidências: fundamentos para a pesquisa clínica. São Paulo: Lemos-Editorial; 1998. [acesso 23 fev. 2018].

51. El Dib R. Guia prático de medicina baseada em evidências. 1. ed. São Paulo: Cultura Acadêmica, 2014. (Coleção PROEX Digital-UNESP). [acesso 23 fev. 2018]. Disponível: http:// hdl.handle.net/11449/126244

52. Falavigna S, Teles AR, Braga GL, Barazzetti DO, Lazzaretti LT, Aline C. Instrumentos de Avaliação Clínica e Funcional em Cirurgia da Coluna Vertebral. Coluna/Columna. 2011;10(1):62-7.

53. Aoude A, Amiot LP. A comparison of the modified Tokuhashi and Tomita scores in determining prognosis for patients afflicted with spinal metastasis. Can J Surg. 2014;57(3):188-93.

54. Neves MAO, Mello MP. Antonioli RS, Freitas MRG. Escalas clínicas e funcionais no gerenciamento de indivíduos com Lesões Traumáticas da Medula Espinhal. Rev Neurocienc 2007:15(3):234-9.

55. Daniel JW. Parâmetros de prognóstico de sobrevivência em pacientes com metástases neoplásicas epidurais da coluna vertebral. São Paulo: Faculdade de Ciências Médicas da Santa Casa de São Paulo. Tese (Doutorado em Ciências Médicas); 2013. [Acesso 23 fev. 2018]. Disponível: http://www.fcmsantacasasp.edu.br/images/Pos-graduacao/dissertacoes-e-teses/Pesquisa-cirurgia/doutorado/2013-Jefferson-Walter-Daniel.pd

56. Kirshblum SC, Burns SP, Biering-Sorensen F, Donovan W, Graves DE, Jha A, et al. International standards for neurological classification of spinal cord injury (Revised 2011). J Spinal Cord Med. 2011:34(6):535-46.

57. Ziu E, Masfin FB. Cancer, Metastasis, Spinal. Treasure Island (FL): Stat Pearls Publishing; 2017

58. Sutcliffe P, Connock M, Shyangdan D, Court R, Kandala N B, Clarke A. A systematic review of evidence on malignant spinal metastases: natural history and technologies for identifying patients at high risk of vertebral fracture and spinal cord compression. Health Technol Assess. 2013;17(42);1-274.

59. Lopes Filho J. Metástase para Coluna Vertebral. 13 set 2017 [acesso em 22 de jan 2018] Disponível em: http://joselopesneuro.com.br/2017/09/13/metastase-para-coluna-vertebral/

60. Kushlinskii NE, Gershtein ES, Solov'ev YN, Timofeev YS, Babkina IV, Dolinkin AO, et al. Receptor Activator of Nuclear Transcription Factor NF-DB (RANK), Its Ligand RANKL, and Natural Inhibitor of RANKL Osteoprotegerin (OPG) in the Blood Serum of Patients with Primary Bone Tumors. Bull Exp Biol Med. 2017;163 (4):478-81.

61. Nater A, Martin AR, Sahgal A, Choi D, Fehlings MG. Symptomatic spinal metastasis: A systematic literature review of the preoperative prognostic factors for survival, neurological, functional and quality of life in surgically treated patients and methodological recommendations for prognostic studies. PLOS ONE. 2017;12(2): e0171507.

62. Schestatsky P, Stefani LC, Sanches PR, Silva Neto DP. Torres ILS, Dall-Agnol L, et al. Validation of a Brazilian quantitative sensory testing device for the diagnosis of small fiber neuropathies. Arq Neuropsiquiatr. 2011;69(6):943-8.

63. Bechara AHS, Rosa AF, Risso Neto MI, Tebet MA, Veiga IG, Pasqualini W, et al. Correlação entre a sobrevida real e os escores de Tokuhashi e Tomita em metástases de coluna vertebral. Coluna/Columna. 2015;14(2):138-43.

64. Mattama JL, Freitas RR, Mello GJP, Armani Neto M. Freitas Filho G. Ferreira CB, et al. Estudo da aplicabilidade do escore de Tokuhashi modificado nos pacientes tratados cirurgicamente de metástases vertebrais. Rev Bras Ortop. 2011;46(4):424-30

65. Terret C, Albrand G, Moncenix G, Droz JP. Karnofsky Perfonance Scale (KPS) or Physical Perfonance Test (PPT)? That is the question. Crit Rev Oncol Hematol. 2011:77(2):142-7.

66. Dunning EC, Butler JS, Morris S. Complications in the management of metastatic spinal disease. World J Orthop. 2012;3(8):114-21.

67. Fornazari SA, Ferreira RER. Religiosidade/Espiritualidade em Pacientes Oncológicos: Qualidade de Vida e Saúde. Psicol Teor Pesqui. 2010;26(2):265-72.

68. Tokuhashi Y, Matsuzaki H, Oda H, Oshima M, Ryu J. A revised scoring system for preoperative evaluation of metastatic spine tumor prognosis. Spine (Phila Pa 1976) 2005:30(19):2186-91.

69. Daniel JW, Veiga JCE. Diretrizes no tratamento das metástases epidurais da coluna vertebral: atualização. Arq Bras Neurocir. 2007:26(3):93-110.

70. Joaquim AF, Maturama FAP, Anderle DV, Zambeli HJL, Maldaun MVC. Metástases na coluna vertebral. Rev Neurocienc. 2007:15/3:240-5

71. Eastley N, Neweyb M, Ashford RU. Skeletal metastases - the role of the orthopedic and spinal surgeon. Surg Oncol. 2012:21(3):216-22

72. Delank KS, Wendtner C, Eich HT, Eysel P. The Treatment of Spinal Metastases Dtsch Arztebl Int. 2011;108(5):71-80.

73. Ciftdemir M, Kaya M, Selcuk E, Yalniz E. Tumors of the spine. World J Orthop. 2016;7(2):109-16.

74. Bilskya MH, Lisb E, Raizerc J, Leed H, Bolanda P. The Diagnosis and Treatment of Metastatic Spinal Tumor. Oncologist. 1999;4(6):459-69.

75. Macedo F, Ladeira K, Pinho F, Saraiva N, Bonito N, Pinto L, et al. Bone Metastases: An Overview. Oncol Rev. 2017;11(1):321

76. Próspero JD, Consentino EB, Pedro PR, Yanomine ES, Pozzan G, Voltan K. Fratura em osso patológico. Arq Med Hosp Fac Cienc Med Santa Casa São Paulo. 2014;59(1):27-33.

77. Al-Qurainy R, Collis E. Metastatic spinal cord compression: diagnosis and management. BMJ. 2016;353.

78. National Collaborating Centre for Cancer (UK). Full Guideline - Metastatic Spinal Cord Compression. Diagnosis and Management of Patients at Risk of or with Metastatic Spinal Cord Compression. Cardiff (UK): National Collaborating Centre for Cancer (UK); 2008.

79. L'Espérance S, Vincent F, Gaudreault M, Ouellet JA, Li M, Tosikyan A, et al. Treatment of metastatic spinal cord compression: cepo review and clinical recommendations. Cur Oncol. 2012;19(6):e478-90.

80. Tyler H. Metastatic spinal cord compression. Macmillan professionals: First part of Sharing Good Practice, Summer 2015. [acesso 26 de Jan. 2018]. Disponível em: https://www.macmillan.org.uk/aboutus/healthandsocialcareprofessionals/new sandupdates/macvoice/summer2015/metastaticspinalcordcompression.aspx

81. Simões ASL Compressão Medular Maligna: Uma emergência oncológica. ONCO.NEWS. 2011, 2011.

82. Liberal FDG. Avaliação e caraterização por métodos computacionais de diferentes radioisótopos no contexto da terapia paliativa de metástases ósseas. Dissertação (Mestrado em Engenharia Biomédica), Universidade do Porto. Porto. 2014. [acesso 24 de Set. 2018]. Disponível em:https://web.fe.up.pt/ tavares/downloads/publications/teses/MSc_Francisco Liberal.pdf. 
83. Farias MLF. A Hipercalcemia nas Malignidades: Aspectos Clínicos, Diagnósticos e Terapêuticos. Arq Bras Endocrinol Metab. 2005;49(5):816-24

84. Maciel TAC, Stella LC, Rodrigues VM, Gusmão MPSA, Ântico Filho A. Crise hipercalcêmica - Relato de Caso. Rev Bras Medicina. 2006;13:70-6.

85. Mirrakhimov AE. Hypercalcemia of Malignancy: An Update on Pathogenesis and Management. N Am J Med Sci. 2015;7(11):483-93.

86. Ruppert LM. Malignant Spinal Cord Compression-Adapting Conventional Rehabilitation Approaches. Phys Med Rehabil Clin N Am. 2017;28(1):101-14.

87. Wilkinson AN, Viola R, Brundage MD. Managing skeletal related events resulting from bone metastases. BJM. 2008;208(337):1101-5.

88. Beyaz SG. Comparação das técnicas transforaminal e interlaminar de injeções epidurais de esteroides para o tratamento de dor lombar crônica. Rev Bras Anestesiol. 2017;67(1):21-7.

89. Kim DH, Kim YC, Kim KH. Técnicas Percutâneas Minimamente Invasivas para a coluna vertebral. Rio de Janeiro: Di Livros Editora Ltda; 2013

90. Cho JH, Ha JK, Hwang CJ, Lee DH, Lee CS. Patterns of Treatment for Metastatic Pathological Fractures of the Spine: The Efficacy of Each Treatment Modality. Clin Orthop Surg. 2015;7(4):476-82.

91. Hübner AR, Azevedo VG, Martins M, Suárez ÁDH, Carneiro MF, Ribeiro M, et al. Análise Comparativa de Técnicas de fixação para Fraturas da Coluna Toracolombar. Coluna/Columna. 2011;10(4):275-8.

92. Herrero CFPS, Bressan Neto M, Godoy CES, Fornazari VR, Pacola LM, Nogueira-Barbosa $\mathrm{MH}$, et al. Resultado da cifoplastia no tratamento minimamente invasivo das metástases vertebrais. Coluna/Columna. 2014;13(3):235-8.
93. Cordero NGG, Cordero JORG, Vieira LAG. Vertebroplastia percutânea: uma efetiva técnica cirúrgica minimamente invasiva. Rev Bras Ortop. 2008:43(1-2):15-2.

94. Sohn S, Chung CK. The Role of Stereotactic Radiosurgery in Metastasis to the Spine. J Korean Neurosurg Soc. 2012;51(1):1-7.

95. Braam $P$, Lambin $P$, Bussink J. Stereotactic versus conventional radiotherapy for pain reduction and quality of life in spinal metastases: study protocol for a randomized controlled trial. Trials. 2016;17:61.

96. Ferrão ARC. $O$ tratamento de metástases ósseas de fração única vs múltiplas frações com 3D CRT ou SBRT: artigo de revisão sistemática. Saúde \& Tecnologia. $2015 ; 14: 36-41$.

97. Laufer I, Rubin DG, Lis E, Cox BW, Stubblefield MD, Yamada Y, et al. The NOMS Framework: Approach to the Treatment of Spinal Metastatic Tumors. Oncologist. 2013;18(6):744-51.

98. Barzilai O, Laufer I, Yoshiya Y, Higginson DS, Schmitt AM, Lis E, et al. Integrating Evidence-Based Medicine for Treatment of Spinal Metastases Into a Decision Framework: Neurologic, Oncologic, Mechanicals Stability, and Systemic Disease. J Clin Oncol. 2017;35(21):2419-27.

99. Joaquim AF, Powers A, Laufer I, Bilsky MH. An update in the management of spinal metástases. Arq Neuropsiquiatr. 2015;73(9):795-802.

100. Pantano NP. É possível predizer a sobrevida de pacientes ambulatoriais com câncer avançado quando encaminhados aos cuidados paliativos. Barretos - SP: Fundação Pio XII - Hospital de Câncer de Barretos, 2015. Dissertação (Mestrado Ciências da Saúde). [acesso 3 mar. 2018]. Disponível: http://www.hcancerbarretos.com.br/ upload/doc/4199d9c6efa368e74c94022aff2077f8.pd 